CZASOPISMO INŻYNIERII LĄDOWEJ, ŚRODOWISKA I ARCHITEKTURY JOURNAL OF CIVIL ENGINEERING, ENVIRONMENT AND ARCHITECTURE

JCEEA, t. XXXIII, z. 63 (2/II/16), kwiecień-czerwiec 2016, s. 399-412

\author{
Andrzej RAGANOWICZ ${ }^{1}$ \\ Józef DZIOPAK ${ }^{2}$
}

\title{
STATYSTYCZNA PROGNOZA STANU \\ TECHNICZNEGO KAMIONKOWEJ \\ KANALIZACJI SANITARNEJ \\ W UNTERHACHING
}

\begin{abstract}
Wykonanie pełnozakresowej inspekcji jednorodnej, kamionkowej sieci sanitarnej należącej do bawarskiej gminy Unterhaching oraz przeprowadzenie na tej podstawie badań statystycznych umożliwiło opracowanie prognozy stanu technicznego dla tego obiektu kanalizacyjnego. Prognoza ta oparta jest na pięciu teoretycznych funkcjach przejścia, które sformułowano na bazie rozkładu Weibulla. Funkcje przejścia wyznaczają granice pomiędzy sześcioma stanami techniczno-eksploatacyjnymi. Analiza tych funkcji pozwoliła ustalić konieczny zakres odnowy, czas przebywania odcinków sieci w poszczególnych stanach oraz procentową prędkość ich starzenia się. Realizacja prognozowanego zakresu odnowy zapewnia pełną dyspozycyjność sieci w okresie przynajmniej 10-ciu lat. Wyniki prognozy są miarodajne, ponieważ przedmiotowa sieć zbudowana jest $\mathrm{z}$ jednorodnego materiału i jest eksploatowana $w$ jednorodnych warunkach gruntowo-wodnych.
\end{abstract}

Słowa kluczowe: systemy kanalizacyjne, kamionkowa sieć sanitarna, inspekcja optyczna, statystyczne modelowanie stanu technicznego sieci kanalizacyjnej

\section{Wprowadzenie}

Kamionkowa sieć sanitarna bawarskiej gminy Unterhaching została poddana w roku 2000 pełnozakresowej inspekcji optycznej. Badaniami telewizyjnymi

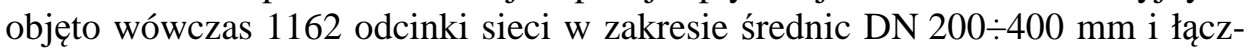
nej długości $39970 \mathrm{~m}$. Stan techniczno-eksploatacyjny przedmiotowej sieci udokumentowano w systemie kodów ISYBAU-96 [1].

Na podstawie podwójnej klasyfikacji wyników inspekcji ustalono pięć klas przejścia, które stanowiły granice pomiędzy sześcioma stanami technicznymi

\footnotetext{
${ }^{1}$ Autor do korespondencji / corresponding author: Andrzej Raganowicz, Zweckverband zur Abwasserbeseitigung im Hachinger Tal, Rotwandweg 16, D-82024 Taufkirchen, tel. +49 8961559050 , e-mail: andreas.raganowicz@azvht.de

2 Józef Dziopak, Politechnika Rzeszowska, Zakład Infrastruktury i Ekorozwoju, al. Powstańców Warszawy 6, 35-959 Rzeszów, tel. +48 17 8651784, e-mail: jdziopak@prz.edu.pl
} 
sieci, tj. od stanu najlepszego bez uszkodzeń do stanu najgorszego porównywalnego z katastrofą budowlaną. Przeprowadzenie wstępnych badań statystycznych dla każdej klasy przejścia pozwoliło ustalić, że empiryczne rozkłady prawdopodobieństwa mają niesymetryczny charakter. Fakt ten sugerował z kolei możliwość zastosowania dwuparametrowego rozkładu Weibulla do dalszych badań statystycznych w celu opracowania prognozy stanu technicznego eksploatowanej sieci kanalizacyjnej w systemie grawitacyjnym.

W wyniku badań statystycznych na bazie modelu Weibulla udało się skonstruować pięć teoretycznych funkcji przejścia od jednej do następnej, gorszej klasy stanu technicznego, które tworzą osnowę planowanej prognozy [2]. Rozkład Weibulla i jego parametry w postaci technicznej żywotności charakterystycznej $T$ i stromości rozkładu $b$ oszacowano w oparciu o analityczną metodę Maximum-Likelihood, która najdokładniej odwzorowywała statystykę materiału empirycznego. Opracowanie prognozy stanu technicznego dla kamionkowej sieci sanitarnej gminy Unterhaching umożliwiło ustalenie przede wszystkim wymaganego zakresu zabiegów renowacyjnych i szeregu ważnych wytycznych dotyczących właściwej eksploatacji badanej infrastruktury kanalizacyjnej.

\section{Zakres badań}

W artykule zaprezentowano końcowe wyniki interdyscyplinarnych badań, polegające na sformułowaniu statystycznej prognozy stanu technicznego kamionkowej sieci sanitarnej gminy Unterhaching w formie pięciu funkcji przejścia, od najlepszej do najgorszej klasy odnowy. Wstępną interpretację funkcji rozkładu prawdopodobieństwa niezawodności przeprowadzono za pomocą prostopadłej przechodzącej przez okres eksploatacji wynoszący 30 lat, która przecina wszystkie krzywe (rys. 1). Punkty przecięcia prostej z wyznaczonymi krzywymi określają prawdopodobieństwo przynależności ustalonych fragmentów kanałów do ściśle określonej klasy odnowy. Odpowiada to jednocześnie udziałowi procentowemu odcinków sieci $\mathrm{w}$ danej klasie. $\mathrm{Z}$ diagramu przestawionego na rysunku 1 wynika, że 30,1\% odcinków sieci jest w bardzo dobrym stanie techniczno-eksploatacyjnym, ponieważ nie wykazują one żadnych uszkodzeń. Zatem należy przyjąć, że jako dopełnienie do 100\% stanowią odcinki kanałów, które wykazują klasę odnowy gorszą od klasy piątej. Z wykresu wynika, że $55,02 \%$ odcinków tej grupy wiekowej nie przekroczyło drugiej klasy. Natomiast dopełnienie do $100 \%$ wynoszące $44,98 \%$ odcinków, których uszkodzenia mają charakter katastroficzny, ponieważ przekroczyło krytyczną granicę stanu technicznego. $\mathrm{Z}$ tego też powodu należy je poddać odnowie.

Szczególnie istotną kwestią w każdej grupie wiekowej kanałów jest długość fragmentu prostej prostopadłej, przebiegającej przez strefę katastrofy budowlanej. W analizowanym przypadku odsetek ten wynosi $27,12 \%$ (rys. 1). Na podstawie funkcji przejścia można ustalić, że około $20 \%$ odcinków sieci ma szansę 
osiągnąć założoną żywotność techniczną 45 lat bez konieczności przeprowadzenia zabiegów renowacyjnych.

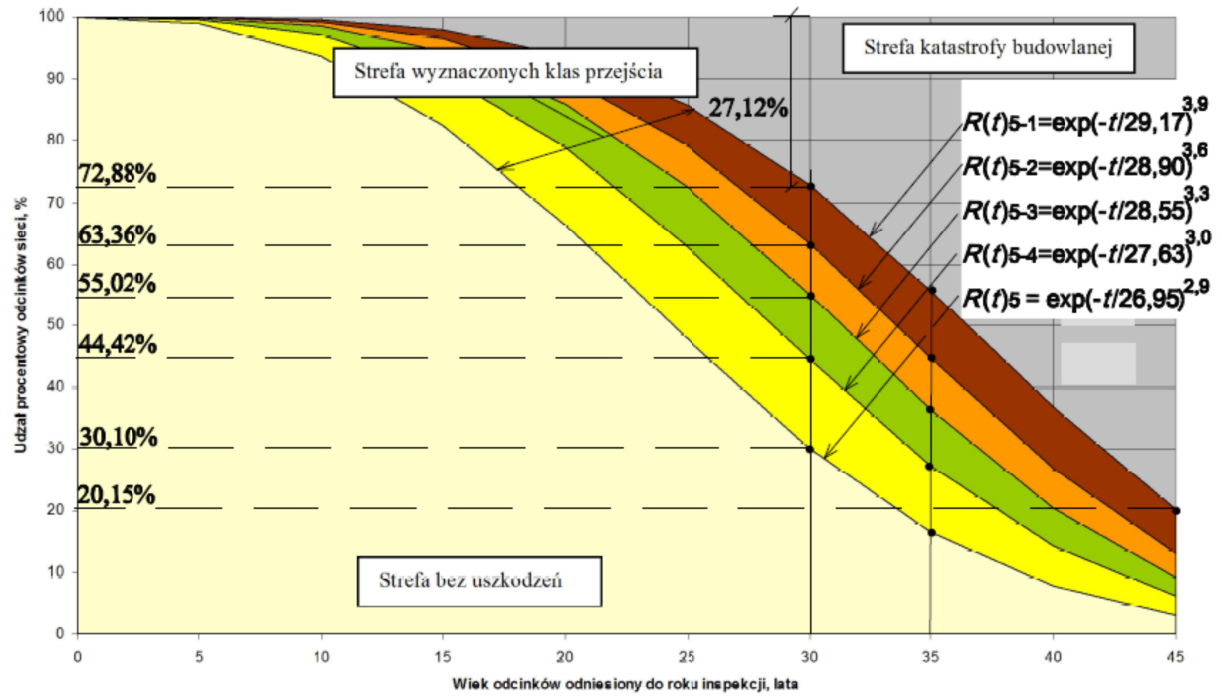

Rys. 1. Teoretyczne funkcje przejścia (niezawodności) R(t) wyznaczone dla kamionkowej sieci sanitarnej na terenie gminy Unterhaching

Fig. 1. Theoretical transition functions (reliability) $\mathrm{R}(\mathrm{t})$ determined for vitrified clay sanitary network in the municipality of Unterhaching

\section{Analiza przebiegu funkcji przejścia (niezawodności) $\mathbf{R}(\mathbf{t})$}

W celu ustalenia niezbędnego zakresu odnowy przeprowadzono analizę krytycznej funkcji przejścia (niezawodności) $R(t)_{5-3}$ wyznaczającej granicę wiekową kanału, od której konieczne jest wykonanie zabiegów renowacyjnych. Dodatkowo określono zakres odnowy w dwóch następnych funkcjach przejścia $R(t)_{5-2}$ i $R(t)_{5-1} \mathrm{w}$ celu porównania wielkości kosztów dla różnych wersjii odnowy. Wyniki ustalonych analiz przedstawiono w tabeli 1.

Z kolei na rysunku 2 przedstawiono trzy wersje odnowy z procentowymi ich zakresami odcinków badanej sieci, eksploatowanych przez 30 lat. Powierzchnia znajdująca się powyżej krzywej $R(t)_{5-3}$ odnosi się do odcinków badanej sieci, którym przyporządkowano drugą i gorsze klasy odnowy. Natomiast powierzchnia znajdująca się poniżej tej funkcji obejmuje odcinki sieci wykazujące klasy odnowy od piątej do trzeciej. Stan techniczno-eksploatacyjny tego fragmentu sieci nie wymaga odnowy, jedynie zabiegów o charakterze konserwacyjnym. Przyjęcie takiego kryterium odnowy, które określa, że odcinki drugiej i pierwszej klasy odnowy muszą być poddawane zabiegom renowacyjnym stanowi analogią do klasyfikacji priorytetowej. Podstawą tych założeń jest klasyfi- 
kacja udokumentowanych uszkodzeń sieci, ustalonych według wytycznych ATV-M 143-2 [3], które uwzględniają podział na katastroficzne i parametryczne.

Tabela 1. Zakres odnowy badanej sieci kamionkowej na bazie trzech funkcji przejścia $R(t)_{5-3}$, $R(t)_{5-2}$ i $R(t)_{5-1}$

Table 1. Scale of renovation of examined vitrified clay network on the basis of three transition functions $R(t)_{5-3}, R(t)_{5-2}$ and $R(t)_{5-1}$

\begin{tabular}{|c|c|c|c|}
\hline $\begin{array}{l}\text { Wiek } \\
\text { odcinków } \\
\text { (lata) }\end{array}$ & $\begin{array}{c}\text { Liczba odcinków } \\
\text { miarodajnych dla } \\
\qquad R(t)_{5-3}\end{array}$ & $\begin{array}{c}\text { Liczba odcinków } \\
\text { miarodajnych dla } \\
R(t)_{5-2}\end{array}$ & $\begin{array}{c}\text { Liczba odcinków } \\
\text { miarodajnych dla } \\
R(t)_{5-1}\end{array}$ \\
\hline 5 & 0 & 0 & 0 \\
\hline 10 & 1 & 1 & 0 \\
\hline 15 & 5 & 3 & 2 \\
\hline 20 & 10 & 6 & 4 \\
\hline 25 & 30 & 23 & 16 \\
\hline 30 & 222 & 181 & 134 \\
\hline 35 & 135 & 117 & 94 \\
\hline 40 & 2 & 1 & 1 \\
\hline 45 & 22 & 21 & 19 \\
\hline $\begin{array}{l}\text { Suma liczby } \\
\text { odcinków }\end{array}$ & 427 & 353 & 270 \\
\hline $\begin{array}{c}\text { Zakres } \\
\text { odnowy (\%) }\end{array}$ & 36,75 & 30,38 & 23,24 \\
\hline
\end{tabular}

Przebieg funkcji przejścia $R(t)_{5-3}$ charakteryzuje się widocznym załamaniem, które występuje po upływie 25-ciu lat eksploatacji badanej sieci. Po jego upływie coraz większy odsetek odcinków przechodzi z trzeciej do drugiej klasy odnowy. Jest to ogólna tendencja potwierdzona prowadzonymi obserwacjami i obejmuje wszystkie krzywe oprócz $R(t)_{5}$. Autor pracy doktorskiej [2], opartej na bardzo dużej próbie losowej przewodów kanalizacyjnych o łącznej długości 450-ciu km wykazał, że obiekty tego typu funkcjonują bezawaryjnie $\mathrm{z}$ reguły przez około 30 lat. Po takim okresie eksploatacji sieci kanalizacyjnej zachodzi konieczność przeprowadzenia zabiegów renowacyjnych.

Mnożąc kolejno odsetki odcinków wymagających odnowy, stosując trzy jej wersje przez liczbę odcinków należących do odpowiednich grup wiekowych, 
a następnie sumując uzyskane wyniki wyznaczono trzy charakterystyczne zakresy odnowy:

- zakres odnowy ustalony dla funkcji $R\left(t_{5-3} \rightarrow \mathbf{3 6 , 7 5 \%}\right.$,

- zakres odnowy ustalony dla funkcji $R(t)_{5-2} \rightarrow 30,38 \%$,

- zakres odnowy ustalony dla funkcji $R(t)_{5-1} \rightarrow 23,24 \%$.

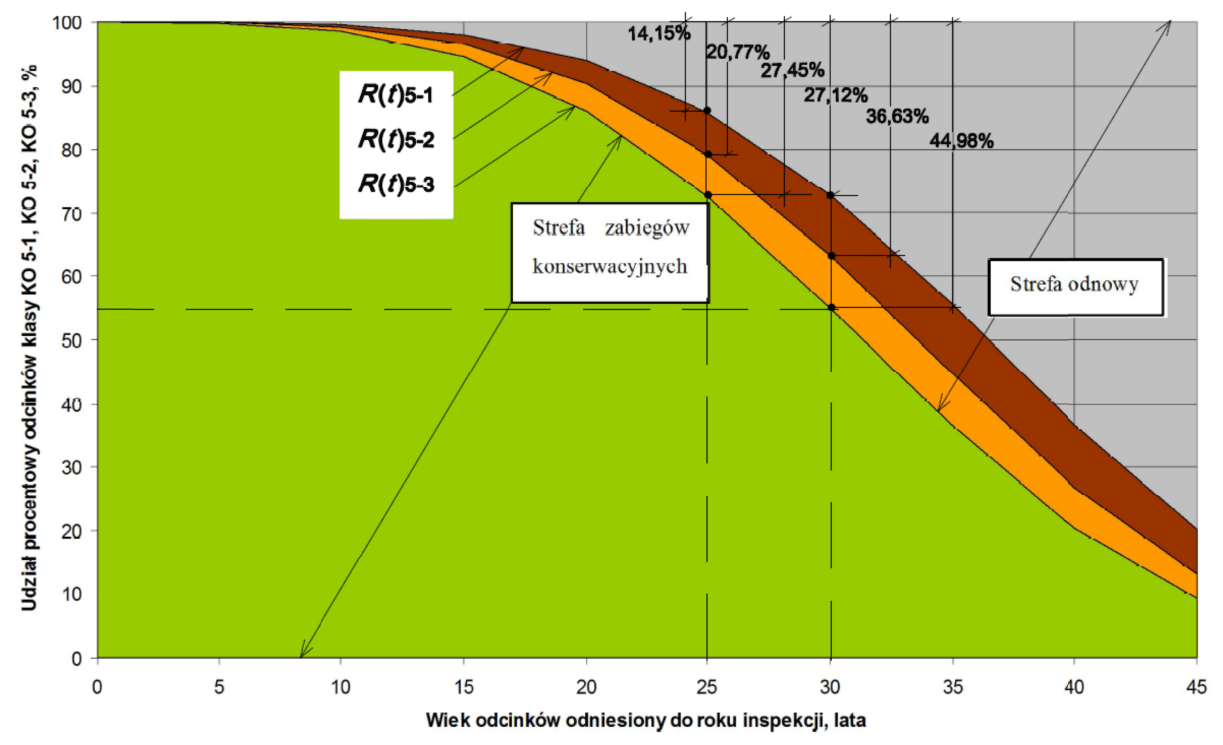

Rys. 2. Ustalanie liczby odcinków sieci podlegających odnowie

Fig. 2. Determination of the number of network sections subject to renewal

Pełny zakres odnowy sieci kanalizacyjnej gminy Unterhaching, zgodnie z przeprowadzoną prognozą jej stanu technicznego obejmuje 36,75\% wszystkich odcinków sieci. Odnosząc to do całej badanej sieci kanałów, odpowiada ona liczbie 427 odcinków, które powinny zostać poddane rehabilitacji technicznej, i to na całej długości. Absolutnie konieczny zakres odnowy, który określono bazując na funkcji przejścia $R(t)_{5-1} \mathrm{z}$ krótkoterminową realizacją wynosi $23,24 \%$, czyli prawie jednej czwartej wszystkich eksploatowanych kanałów i odpowiada liczbie 270 odcinków sieci.

Ustalony na podstawie prognozy statystycznej pełny zakres odnowy obejmujący $36,75 \%$ odcinków sieci odbiega w sposób zdecydowany od zakresu, jaki wyznaczono na podstawie klasyfikacji priorytetowej, który wynosil zaledwie $20 \%$ [4]. Rozbieżność między tymi dwoma prognozami wynika z faktu, że klasyfikacja realna stanowi bazę prognozy statystycznej i jest oparta na strategii renowacyjnej, której wynikiem jest zachowanie wartości substancji budowlanej badanej sieci kamionkowej na odpowiednio wysokim poziomie. Prewencyjny charakter tej strategii powoduje, że koszty odnowy w fazie jej realizacji są bar- 
dzo wysokie. Wysokie koszty odnowy stają się relatywne wówczas, gdy w analizie kosztów i efektów ekonomicznych uwzględnia się zakładane żywotności techniczne, zarówno w odniesieniu do odnowy, jak i konserwacji sieci.

$\mathrm{Z}$ porównania strategii podejmowania decyzji wynika, że wbudowanie do określonego fragmentu odcinka sieci trzech krótkich rękawów jest z punktu widzenia technicznego i ekonomicznego mniej opłacalne niż wbudowanie jednego kompletnego rękawa na całej długości $[5,6]$. Rehabilitacja techniczna określonego odcinka sieci w formie pełnego rękawa pozwala założyć jego czterdziestoletnią żywotność techniczną, natomiast w przypadku jego konserwacji tylko okres dziesięcioletni.

Jako wariantową opcję w analizie kosztów wydatkowanych przy stosowaniu różnych rozwiązań renowacyjnych należy także uwzględnić wymianę wykopową, dla której przyjmuje się obecnie jako realną żywotność wynoszącą aż 80 lat. Istotne zatem jest porównanie rzeczywistych kosztów wymiany bezwykopowej lub wykopowej, odnowy oraz konserwacji. W tym celu ustalono i zdefiniowano określone wskaźniki kosztów, które uwzględniają żywotność techniczną i jej amortyzację, biorąc pod uwagę różne rozwiązania techniczne odnowy kanałów. Wskaźniki te zostały ustalone przez wytyczne niemieckie LAWA [7] i przyjmują dla powyższych żywotności technicznych zróżnicowane wartości. Biorąc pod uwagę ustalone żywotności badanej sieci, przyjmują one następujące wartości:

- konserwacja (prace wykonane przez roboty) 3,6040,

- odnowa (technika reliningu) 1,3171,

- wymiana wykopowa (przewody kamionkowe) 1,0000.

Okazuje się, że powyższe wskaźniki są bardzo praktycznym instrumentem umożliwiającym przeprowadzenie porównawczej analizy w kontekście decyzji dotyczącej wyboru najbardziej ekonomicznego rodzaju odnowy. W praktyce eksploatacyjnej bardzo często zastępuje się odnowę zabiegami konserwacyjnymi, co w efekcie prowadzi do skutecznej redukcji kosztów przeznaczanych na odnowę. Pozwala takie podejście na wykonanie wielokrotnych zabiegów konserwacyjnych, wymagających niskich nakładów finansowych każdy i rozłożonych w czasie na małe kwoty.

Innymi ważnymi parametrami, które można odczytać z wyznaczonego diagramu przebiegu funkcji przejścia są, zarówno czas ,,przebywania” wybranych odcinków sieci w poszczególnych klasach odnowy, jak i procentowa prędkość starzenia się tych fragmentów kanałów. W celu ustalenia czasu przebywania odcinków w każdej klasie odnowy należy przeprowadzić prostą równoległą do osi odciętych na poziomie 50\%. Prosta ta przecina wszystkie funkcje przejścia $R(t)$, wyznaczając w ten sposób przedziały czasowe, które odpowiadają poszczególnym klasom odnowy. Odmierzając odstępy między środkami powstałych przedziałów czasowych wyznaczono z 50\% prawdopodobieństwem czasy „,przebywania" odcinków w ramach kolejnych klas odnowy (rys. 3), które przyjmują kolejno podane wartości: 
- klasa odnowy KO 5 - 10,0 lat,

- klasa odnowy KO 4 - 3,6 lat,

- klasa odnowy KO 3 - 2,6 lat,

- klasa odnowy KO 2 - 2,7 lat,

- klasa odnowy KO $1-5,7$ lat.

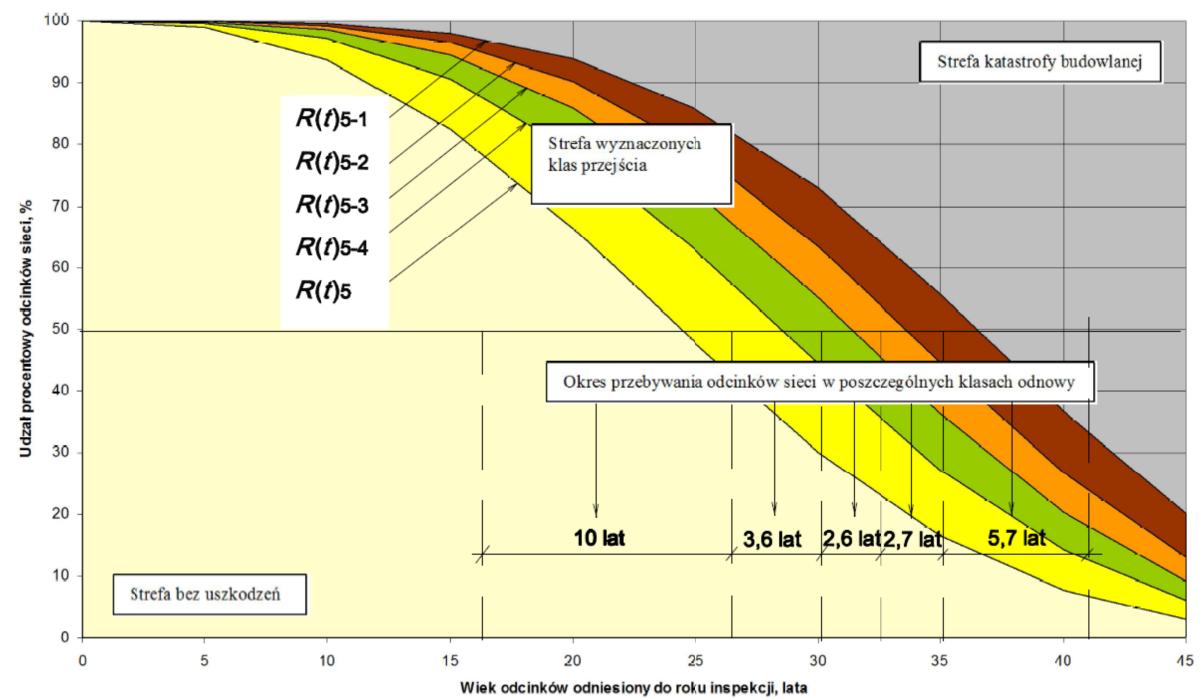

Rys. 3. Prognoza określająca czas ,przebywania” odcinków badanej sieci w poszczególnych klasach odnowy

Fig. 3. Forecast of the "residence" time of examined network sections in each class of renovation

Z analizy czasów „przebywania” określonej liczby odcinków sieci w poszczególnych klasach odnowy wynika, że ich średnia wartość wynosi niecałe 5 lat. Informacja ta ma duże znaczenie praktyczne dla firm odpowiedzialnych za eksploatację sieci kanalizacyjnej, ponieważ pozwala ona ustalić zalecany przedział czasu pomiędzy kolejnymi inspekcjami sieci. Prowadzenie inspekcji w cyklu wynoszącym $3 \div 5$ lat zapewnia w przypadku badanej sieci kamionkowej możliwość zaobserwowania propagacji różnego typu uszkodzeń, które w opracowanej prognozie są opisane przez przechodzenie odcinków z jednej do innej, gorszej klasy odnowy. Wytyczna ta znajduje potwierdzenie w amerykańskiej praktyce eksploatacyjnej, stosującej standardowo pięcioletni cykl inspekcji optycznej. Prowadzenie badań telewizyjnych z taką częstotliwością umożliwia zastosowanie stochastycznego modelu Markov'a do prognozowania przebiegu procesów starzeniowych sieci i obiektów kanalizacyjnych, co potwierdzono badaniami $[8,9]$.

Następnym parametrem, jaki wyznaczono na podstawie przebiegu funkcji niezawodności jest średnia procentowa prędkość starzenia się badanych odcin- 
ków sieci. Prędkość ta w każdej klasie odnowy wzrasta wraz z wiekiem eksploatacji kanałów. Rozpoczyna się od zera do wartości maksymalnej wynoszącej 30 lat i następnie maleje aż do osiągnięcia przez analizowane odcinki kanałów wieku 45 lat (rys. 4). Parametr ten zdefiniowano jako powierzchnie należące do poszczególnych klas odnowy. Średnia procentowa prędkość starzenia się badanych odcinków sieci, które należą do trzeciej klasy odnowy (KO 3), przyjmuje określone wartości, biorąc pod uwagę wiek odcinków odniesiony do roku inspekcji, i tak:

- 5 lat $0,2 \%$,

- 10 lat $1,4 \%$,

- 15 lat $3,8 \%$,

- 20 lat $7,0 \%$,

- 25 lat $9,7 \%$,

- 30 lat $\mathbf{1 0 , 6 \%}$,

- 35 lat $9,2 \%$,

- 40 lat $6,2 \%$,

- 45 lat $3,2 \%$.

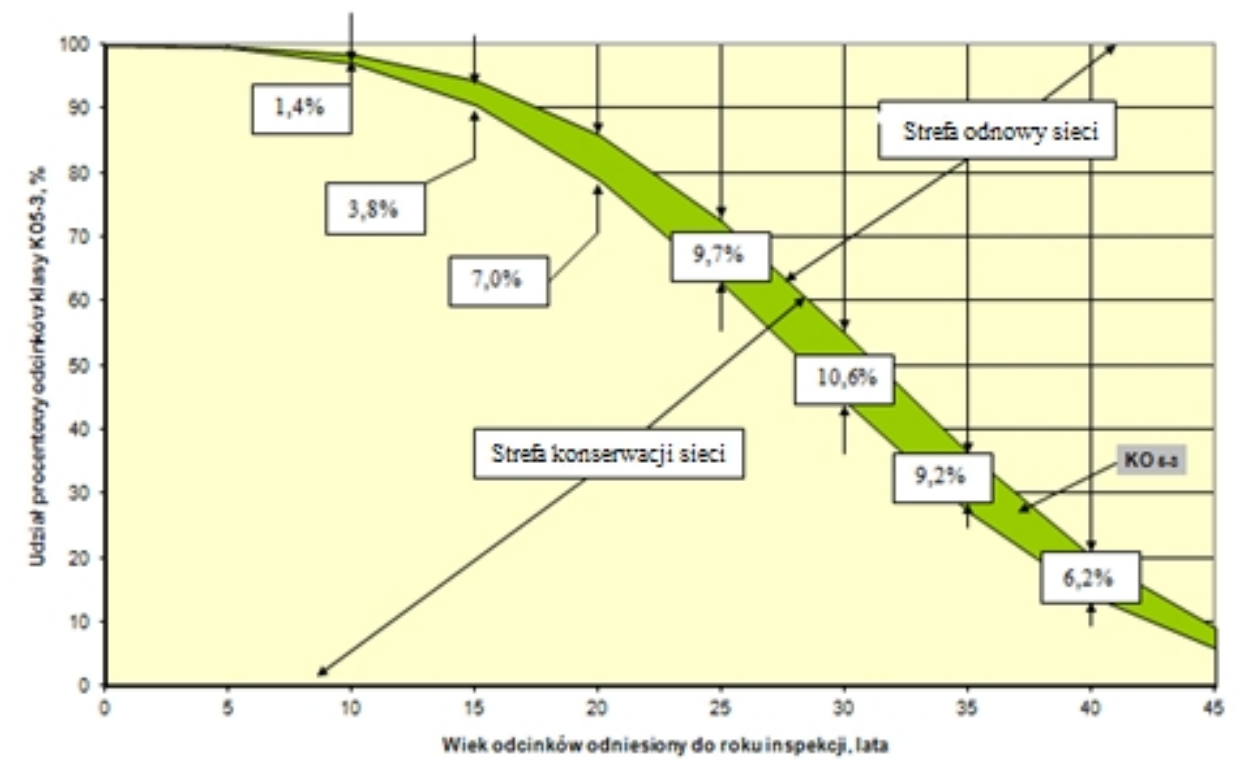

Rys. 4. Prognoza tempa starzenia się kamionkowej badanej sieci sanitarnej wyrażona jako prawdopodobieństwo w procentach

Fig. 4. Forecast of aging rate of examined vitrified clay sanitary network expressed as a probability percentage

Osiągnięcie przez odcinki badanej sieci, eksploatowanej przez 30 lat maksymalnej prędkości starzenia się jest typowym zjawiskiem dla każdej klasy od- 
nowy. Jest to analogia do funkcji przejścia, których punkty przegięcia odpowiadają także trzydziestoletniej eksploatacji badanej sieci. Po tym charakterystycznym okresie funkcjonowania obiektu następuje nagły wzrost liczby odcinków sieci, które należy klasyfikować w następnej, gorszej klasie odnowy.

\section{Badania intensywności uszkodzeń $\lambda(t)$ sieci kanalizacyjnej}

Intensywność uszkodzeń $\lambda(t)$ jest informacją podającą w pewnej chwili eksploatacji $t$ liczbę jednostek odniesioną do jednostek sprawnych, które ulegną awarii. Adaptując ten problem dla potrzeb dowolnej sieci kanalizacyjnej można ten parametr zdefiniować jako prawdopodobieństwo przejścia pewnego odcinka lub grupy odcinków od jednej do następnej, gorszej klasy odnowy. Jeżeli znane są parametry teoretycznego rozkładu Weibull'a, to intensywność uszkodzeń można wyznaczyć na podstawie zależności [10]:

$$
\lambda(t)=\frac{b}{T} \cdot\left(\frac{t}{T}\right)^{b-1}
$$

gdzie: $t$ - czas eksploatacji obiektu, lata;

$T$ - żywotność charakterystyczna, lata;

$b$ - parametr formy, czyli stromości rozkładu.

Przebieg krzywych intensywności uszkodzeń dla wszystkich klas odnowy przedstawiono na rysunku 5. Krzywe te wzrastają monotonicznie wraz z wiekiem przewodów kanalizacyjnych, co automatycznie lokalizuje je w trzecim obszarze wanny intensywności uszkodzeń, przedstawionej schematycznej na rysunku 6. Charakter ich przebiegu zależy przede wszystkim od wartości parametru $b$, który charakteryzuje formę rozkładu Weibulla.

W ramach prowadzonych badań kamionkowej sieci sanitarnej gminy Unterhaching okazuje się, że parametr $b$ przyjmuje wartości większe od jedności dla każdej klasy odnowy. Należy udokumentowane uszkodzenia interpretować jako wynik zużycia materiału roboczego przewodów kanalizacyjnych. W przewodach kamionkowych, z których wyłącznie zbudowana jest badana sieć, najbardziej podatnym elementem na zużycie są uszczelnienia połączeń rur. Charakter przebiegu krzywych intensywności uszkodzeń jest analogiczny do przebiegu funkcji niezawodności w tym sensie, że prawdopodobieństwo przejścia odcinków do następnej, gorszej klasy odnowy, które nie przekroczyły jeszcze wieku 25 lat, jest mniejsze niż dla odcinków starszych. W związku z tym nachylenie intensywności uszkodzeń na odcinkach kanałów, które nie osiągnęły jeszcze wieku 25-ciu lat jest mniejsze niż w odcinkach starszych. 


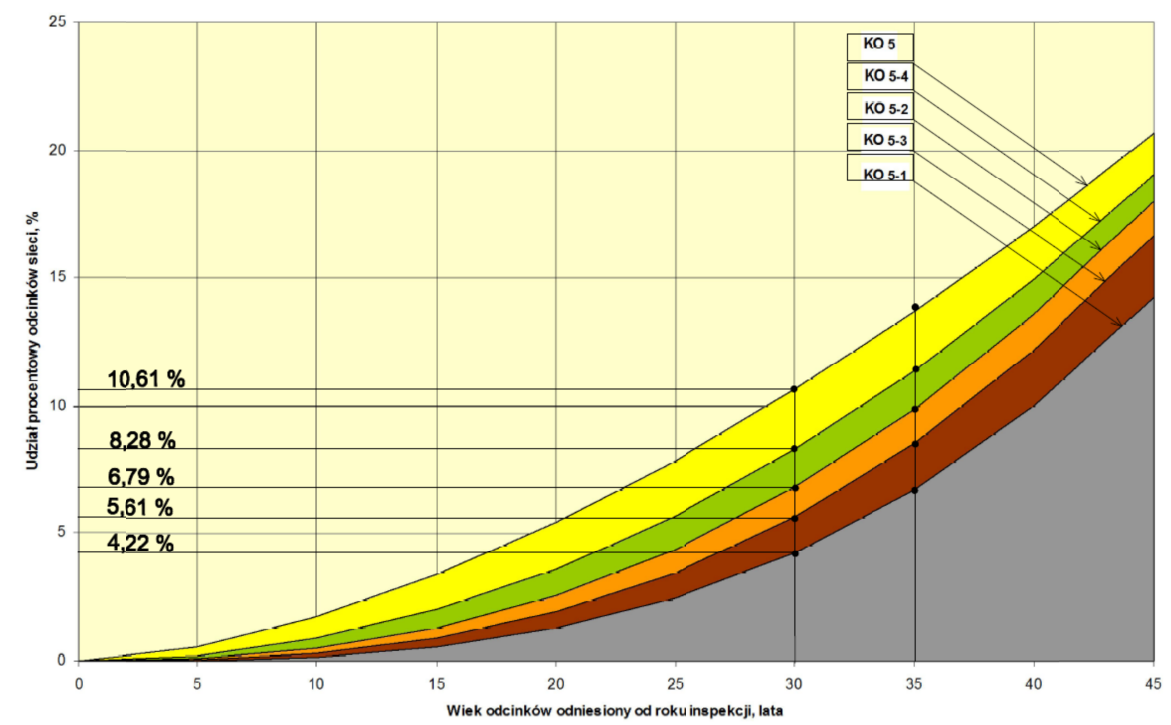

Rys. 5. Intensywność uszkodzeń $\lambda(\mathrm{t})$ wyrażająca prawdopodobieństwo przejścia odcinków kamionkowej sieci sanitarnej od lepszej do gorszej klasy odnowy

Fig. 5. The failure rate $\lambda(\mathrm{t})$ expressing the probability of transition of vitrified clay sanitary network sections from better to worse renovation class

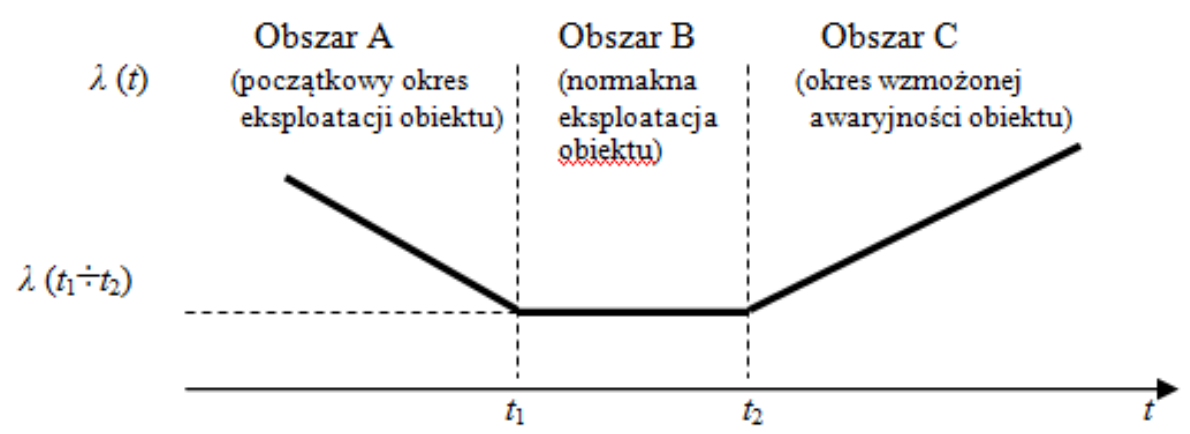

Rys. 6. Schematyczny przebieg krzywej intensywności uszkodzeń dla obiektów mechanicznych i budowlanych

Fig. 6. Schematic course of damage intensity curve for building and mechanical objects

Zatem prawdopodobieństwo przejścia odcinków od jednej do innej, gorszej klasy odnowy i wykazujących dobry stan techniczno-eksploatacyjny jest większe niż w przypadku odcinków znajdujących się w gorszym stanie technicznym. Tendencja ta ma logiczne uzasadnienie, ponieważ w przypadku dobrego stanu 
technicznego kanału, już jego niewielkie uszkodzenie może spowodować przejście do następnej, gorszej klasy odnowy.

$\mathrm{W}$ grupie gorszych klas odnowy dochodzi do zmiany klasy tylko w wyniku działania poważnego wymuszenia zewnętrznego lub wewnętrznego, które nie występuje często, a więc zgodnie $\mathrm{z}$ rysunkiem 5 jest mało prawdopodobne. Prawdopodobieństwa przejścia $\lambda(t)$ od jednej do innej, gorszej klasy odnowy odcinków kanałów eksploatowanych przez 30 lat wynoszą odpowiednio:
- $\lambda\left(t_{i}=30\right)_{K O 5}$
$10,61 \%$,
- $\lambda\left(t_{i}=30\right)_{K O 5-4}$
$8,28 \%$,
- $\lambda\left(t_{i}=30\right)_{K O 5-3}$
$6,79 \%$,
- $\lambda\left(t_{i}=30\right)_{K O 5-2}$
$5,61 \%$,
- $\lambda\left(t_{i}=30\right)_{K O 5-1}$
$4,22 \%$

$\mathrm{Z}$ analizy zestawionych powyżej wartości wynika, że prawdopodobieństwo opuszczenia piątej klasy odnowy przez odcinki badanej sieci, które funkcjonują od 30 lat, wynosi 10,61\%, a opuszczenie pierwszej klasy i przejścia do stanu krytycznego wynosi $4,22 \%$. Natomiast różnice prawdopodobieństw opuszczenia przez odcinki sieci poszczególnych klas odnowy mieszczą się w przedziale $1,18 \div 2,33 \%$.

Parametr intensywności uszkodzeń $\lambda(t)$ jest zarówno identyfikatorem zużycia (starzenia się) infrastruktury kanalizacyjnej, jak również jej kondycji techniczno-eksploatacyjnej. Charakteryzuje on w indywidualny sposób badany obiekt i stanowi ważną informację, która uzupełnia dane dotyczące czasów „przebywania” badanych odcinków sieci w poszczególnych klasach odnowy. Dlatego też powinien być on brany pod uwagę przy ustalaniu długości cykli inspekcji optycznych. Parametr intensywności uszkodzeń i relatywna wartość substancji budowlanej sieci tworzą dwa ważne wyznaczniki, których analiza jest niezbędnym komponentem racjonalnej eksploatacji każdej infrastruktury kanalizacyjnej.

Wyznaczenie funkcji przejścia odcinków od jednej do innej klasy odnowy i sporządzenie na tej bazie prognozy stanu technicznego dla kamionkowej sieci sanitarnej gminy Unterhaching daje podstawy do zdefiniowania wielu zasad i wytycznych jej racjonalnej eksploatacji. Najważniejszym ustaleniem wynikającym z przeprowadzonej prognozy jest ilościowy zakres niezbędnej odnowy, która umożliwia racjonalne wykorzystanie posiadanego do dyspozycji potencjału sił i środków oraz zasobów finansowych.

Realizacja prognozowanego zakresu odnowy zapewni bezawaryjną eksploatację badanej sieci i jej pełną dyspozycyjność w perspektywie dłuższego okresu czasu. Zaproponowana w pracy metodyka sporządzania prognozy stanu technicznego sieci na bazie statystycznego modelu Weibulla ma z uwagi na wielkość zastosowanej bazy danych wzorcowy charakter dla każdej kamionkowej sieci sanitarnej. Duży udział kamionkowych przewodów w infrastrukturach komunalnych, a szczególnie w przypadku dużych polskich i europejskich aglomeracji 
miejskich powinna przyczynić się do popularyzacji praktycznych zastosowań sformułowanej metodyki $\mathrm{w}$ celu racjonalizacji eksploatacji istniejących systemów kanalizacyjnych.

\section{Podsumowanie i wnioski}

Metodologię sporządzania prognozy stanu technicznego sieci kanalizacyjnej opracowano wykorzystując bogatą bazę danych eksploatacyjnych kamionkowej kanalizacji sanitarnej, która odprowadza ścieki bytowo-gospodarcze z gminy Unterhaching w Bawarii. Podstawy teoretyczne nowatorskiej metodyki oparto na dwuparametrowym modelu Weibull'a. Natomiast docelowe rozwiązanie interdyscyplinarnego problemu naukowego wymagało rozwiązania wielu zadań cząstkowych. Przyjęto określone założenia i warunki brzegowe funkcjonowania rozległego obiektu badań w różnych lokalnych uwarunkowaniach gruntowo-wodnych. Finalny cel podjętych badań wymagał realizacji kompleksowego programu badań, który obejmował sześć faz i bazował na szerokim spektrum analiz statystycznych.

Dysponując pełnozakresową inspekcją badanej sieci (faza 1), dokonano klasyfikacji priorytetowej wyników inspekcji optycznej i utworzono pięć klas priorytetowych (faza 2), od klasy piątej, najlepszej (KP 5) do klasy pierwszej, najgorszej (KP 1). Następnie sporządzono realną klasyfikację wyników inspekcji optycznej (faza 3), która uwzględnia warunki techniczno-technologiczne planowanej odnowy. Kolejnym etapem (faza 4) były badania statystyczne bazy danych obejmujące wyznaczenie dla każdej klasy przejścia empirycznej funkcji gęstości prawdopodobieństwa przejścia odcinków sieci od określonej do innej klasy odnowy, funkcji awaryjności, funkcji przejścia (niezawodności) oraz intensywności uszkodzeń. Dwa ostatnie zrealizowane zadania obejmowały wyznaczenie teoretycznej funkcji przejścia (faza 5) dla każdej klasy przejścia w oparciu o model Weibulla i najważniejszy efekt przeprowadzonych badań (faza 6), stanowiący sformułowaną prognozę ustalania stanu techniczno-eksploatacyjnego badanej sieci. Końcowa forma tej prognozy w postaci algorytmów obliczeniowych ma uniwersalny charakter i z powodzeniem można ją wdrażać na innych eksploatowanych obiektach liniowych grawitacyjnych systemów kanalizacyjnych.

Sformułowany model prognozy stanu technicznego może być z powodzeniem zastosowany w przypadku każdej kamionkowej sieci sanitarnej. Ma on również uniwersalny charakter, ponieważ warunkiem koniecznym do jego realizacji są wyniki inspekcji optycznej udokumentowane w taki sposób, aby możliwa była ich interpretacja techniczna i ustalenie wieku wszystkich odcinków badanej sieci. Po wykonaniu odpowiedniego skalowania prowadzi się jego aplikację $\mathrm{w}$ celu prognozowania stanu technicznego dowolnego rodzaju sieci kanalizacyjnej. Z uwagi na swoją prostą strukturę, standardową bazę danych oraz nie- 
skomplikowany algorytm zapisu matematycznego, ma on wszelkie dane stać się praktycznym narzędziem racjonalnej eksploatacji sieci kanalizacyjnych.

Przeprowadzone badania statystyczne i analiza wyników prognozy stanu techniczno-eksploatacyjnego analizowanej sieci pozwoliły na sformułowanie wielu wniosków o znaczeniu poznawczym i mających aplikacyjny charakter.

1. Sformułowana prognoza do oceny stanu technicznego sieci kanalizacyjnej jest wiarygodna, ponieważ została sporządzona w oparciu o miarodajną próbę losową, która obejmuje wyniki pełnozakresowej inspekcji optycznej jednorodnej kamionkowej sieci sanitarnej składającej się z 1162 odcinków kanałów o łącznej długości prawie $40 \mathrm{~km}$.

2. Ciągły proces starzenia się badanej sieci kanalizacyjnej został przedstawiony za pomocą sformułowanych teoretycznych funkcji niezawodności, na podstawie których wyznacza się granice pomiędzy sześcioma stanami techniczno-eksploatacyjnymi kanałów. Wyrażają one prawdopodobieństwo ,przejścia” określonych odcinków sieci od stanu najlepszego, czyli bez uszkodzeń przez kolejne wybrane, aż włącznie do granicznego stanu, jakim jest wystąpienie katastrofy budowlanej.

3. Na podstawie opracowanej metody określania przebiegu funkcji przejścia od jednego do innego stanu technicznego, można ustalić ilościowy zakres odnowy, który gwarantuje efektywne gospodarowanie środkami finansowymi i racjonalną eksploatację badanej sieci.

4. Opracowana metodyka może być bezpośrednio wdrożona do praktyki eksploatacyjnej każdej kamionkowej sieci sanitarnej. Natomiast w przypadku innych infrastruktur kanalizacyjnych, można ją przenosić, jednak pod warunkiem wprowadzenia odpowiednich wskaźników lub innych parametrów korygujących.

\section{Literatura}

[1] BMVBS, Arbeitshilfen Abwasser: Planung, Bau und Betrieb von abwassertechnischen Anlagen in Liegenschaften des Bundes, 2005.

[2] Raganowicz A.: Metodyka prognozowania stanu technicznego sieci kanalizacyjnej, Praca doktorska, Instytut Inżynierii Lądowej Politechniki Wrocławskiej, Wrocław 2010.

[3] Merkblatt ATV-M 143-2: Optische Inspektion - Inspektion, Instandsetzung, Sanierung und Erneuerung von Abwasserkanälen und -leitungen, April 1999.

[4] Sanierung des Kanalnetzes in Unterhaching, Ingenieurbüro Steinbacher, Neusäß, 2002.

[5] ATV-DVWK-M 143-7: Reparatur von Abwasserleitungen und -kanälen durch Kurzliner und Innenmanschetten, Merkblatt, April 2003.

[6] DWA-M 143-3: Sanierung von Entwässerungssystemem außerhalb von Gebäuden, Teil 3: Schlauchliningverfahren (vor Ort härtendes Schauchlining) für Abwasserleitungen und -kanäle, Merkblatt, 21.11.2005. 
[7] Länderarbeitsgemeinschaft Wasser (LAWA) Leitlinien zur Durchführung dynamischer Kostenvergleichsrechnung (KVR-Leitlinien), Kulturbuch-verlag GmbH, Berlin 2005.

[8] Abraham D. M., Wirahadikusumah R.: Development of prediction models for sewer deterioration; Proceedings of the Eight International Conference on Durability of building materials and components, Ottawa 1999.

[9] Abraham D. M., Wirahadikusumah R.: Application of dynamic programming and simulation for sewer management, Contruction Architectural Managenent, Vol. 10, $\mathrm{Nr} 2,2003$.

[10] Wilker H.: Weibull-Statistik in der Praxis, Leitfaden zur Zuverlässigkeitsermittlung technischer Produkte, Verlag: Books on Demand GmbH, Nordestedt, 2004.

\section{STATISTICAL FORECAST OF TECHNICAL STATE OF VITRIFIED CLAY SEWAGE SYSTEM IN UNTERHACHING}

\section{S u m m a r y}

The performance of full- range inspection of homogeneous vitrified clay sanitary network belonging to the Bavarian municipality Unterhaching and based on this the statistical research enabled the development of the forecast of technical condition of this sewage object. This forecast is based on five theoretical functions of transition, which was formulated based on the Weibull distribution. Functions of transitions define the boundaries between six technical and exploitation states . Analysis of these features helped to determine the required scale of renovation, the residence time of network sections in each state and percentage aging rate. Implementation of the forecasted scale of renovation provides the full availability of the network during the period of at least 10 years. Forecast results are meaningful, since the present network is built of homogeneous material and is operated in homogeneous soil and water conditions.

Keywords: sewage systems, vitrified clay sanitary network, optical inspection, statistical modelling of sewerage network technical condition

DOI: $10.7862 /$ rb.2016.174

Przestano do redakcji: 01.05.2016 $r$.

Przyjęto do druku: 28.06.2016 r. 